\title{
Female undergraduate sports participation and adequate education, perceived implications of reproductive health problems/male dominance: University sports administration experience
}

\author{
Eugene $\mathrm{AC}^{1 *}$, Adline $\mathrm{AC}^{2}$, Blessing I Chike-Ijezie ${ }^{3}$, Edith $\mathrm{AA}^{1}$ and Charles $\mathrm{UO}^{1}$ \\ ${ }^{1}$ Department of Human kinetics and Health Education, Faculty of Education, Nnamdi Azikiwe University, Awka \\ ${ }^{2}$ Department of educational Management and policy, Faculty of Education, Nnamdi Azikiwe University, Awka \\ ${ }^{3}$ Department of medicine and Surgery, Nnmadi Azikiwe university, Teaching Hospital, Nnewi Campus, Nnewi
}

\begin{abstract}
This study sought to examine female undergraduates sports participation and adequate education, perceived implications of reproductive health problems/male dominance: University Sports administration experience. Sports has grown from its earlier humble beginnings of being a mere entertainment and recreational passtime, to becoming a prominent, business both in the social, political and economic circles of all nations of the world. Hence the researcher tried to verify perceived implications of the reproductive health problems of the girl-child and persistent male dominance in University sports vis a vis female undergraduates participation in sports and their education. Consequently, the specific objective of this study was to verify if the reproductive health problems of the girl-child, poorly funded and maintained sports facilities of the universities and perceived male dominance over the girls in virtually all sports determine female undergraduates participation in university sports and their education generally. To guide this study 3 research questions were formulated, with 3 corresponding hypotheses that were tested at 0.05 level of significance. The descriptive survey research design was considered appropriate, while the instrument for data collection was a self-structured questionnaire designed after the Likert type by the researcher. Total of 380 female undergraduates of three universities in Anambra State of Nigeria. Nnamdi Azikiwe University, Awka, Odumegwu Ojukwu University Uli, and Madonna University Elele Port Harcourt (Federal, State- and Privately-owned universities) constituted the population of the study, out of which a total of 263 respondents were sampled. The descriptive statistics of mean, frequency counts and standard deviation (SD) were used to describe the data, while inferential statistics of Chi-square $\left(\mathrm{X}^{2}\right)$ was used to test the 3 null hypotheses at 0.05 level of significance. Based on the data collected and analyzed, revealed that reproductive health problems $\left(X^{2}=84.18, \mathrm{df}=3, \mathrm{P}>0.05\right)$, poor funding/maintenance of sports for faculties $\left(\mathrm{X}^{2}=75.412\right.$, $\left.\mathrm{df}=3, \mathrm{P}>0.05\right)$ male undergraduates dominance in all sports $\left(\mathrm{X}^{2}=128.68 \mathrm{df} .3, \mathrm{P}>0.05\right)$ were seen to be determinants of female undergraduates participation and education generally in universities. It was therefore recommended that stiffer measures must be taken and applied to preserve the few sports facilities built around the female hostels, to be strictly used by the female undergraduates, at their convenience. Universities need to further improve on their reproductive health service delivery, to adequately cater for the needs of the female undergraduates who presently seem to be on their own, in terms of solutions to their numerous reproductive health problems that tend to interfere with their sports participation and academic pursuits in the university. Highly qualified Nurses should be employed to serve as Matrons attached to all female hostels in the universities to assist the female undergraduates cope with their reproductive health problems at beck and call.
\end{abstract}

\section{Introduction}

There is an urgent and very important, need to always protect and preserve the rights and privileges of the girl-child. Even from the Biblical point of view, they are described as weaker vessels. In so many ways the girl-child is denied most of the vital good things of life, eg. Easy access to participation in physical activities and education. Despite the acclaimed benefits an individual stand to gain from sustained/ regular participation in physical activities and sound education, the girl-child seem to suffer neglect as the disabled individuals of typical Nigerian society [1].

Disability may be described as an umbrella term covering any kind of impairment, activity limitations of all sorts. Impairment could be regarded as any form of problem in the body function or structure. While activity limitation,, is various forms of difficulties, encountered by an individual in executing a task or an action [2], furthermore, participation restriction may be viewed as any form of problem experienced by an individual in the bid to take part freely in any type of societal activities eg. Sports and other physical activities like class attendance for proper education [3-5], disability may also be viewed as an impairment that may be cognitive, developmental, intellectual, physical, sensory or some combination of these. Similarly, physiological functioning capacity (PFC) is a term relating to an individual's performance level. It gauges one's ability to perform a given physical task of daily life by an individual, and the ease with which the task is performed. PFC is said to decline either with advancement in age, cognitive disorders, natural physiological changes that occasionally

${ }^{\star}$ Correspondence to: Alagbu Chukwubuikem Eugene, Faculty of Education, Nnamdi Azikiwe University, Awka, E-mail: alagbuchukwubuikem@yahoo.co.uk

Key words: reproductive health problems, girl-child, female undergraduates, male dominance, disability, sports activities, participation, university, sports facilities

Received: August 05, 2019; Accepted: August 26, 2019; Published: August 28, 2019 
Eugene AC (2019) Female undergraduate sports participation and adequate education, perceived implications of reproductive health problems/male dominance: University sports administration experience

occurred in an individual's internal organs, all of which may result to labeling an individual as disabled [6-9].

In a similar vein, WHO (2011) [10] was of the view that disability is a contested concept, with different meanings in different context and societies or communities. However, in this study efforts will be made to trace and examine the perceived implications of reproductive health problems of the girl-child (Female undergraduates) of typical Nigerian Universities and persistent Male domineering posture, in relationship to their sports participation and education generally.

Even though it could be assumed that in many developing nations of the world, Nigeria inclusive, education of the girl-child is a priority National policy, yet it is observed that both at primary, secondary and tertiary education levels, female enrollment has persistently remained abysmally lower than that of their male counter parts. The afore mentioned worrisome situation notwithstanding, due to inevitable but controllable reproductive health problems of the girl-child, goes further to restrict the few enrolled ones in schools form regular attendance, to classes and participation in sporting activities. According to Udegbe [11] regular participation in physical activities enables the body of an individual to function effectively in work and leisure activities and resist hypokinetic diseases and to meet emergency situations in sporting activities.

Furthermore physical activities entails all bodily movements performed with the aid of the skeletal muscles which requires energy expenditure and consequently results to the well-being of an individual (WHO 2009) [12]. Furthermore, physical activity encompasses all activities at varying intensities, performed during any time of the day or night geared towards the up-keep and well-being of the human body and organs [13] such activities includes exercises and individuals daily programme, of events. The said integrated physical activities may not be planned, structured, purposeful or repetitive in nature. They include casual walking to a local shop for some purchases or cleaning up of the home. Hence lack of regular physical activities generally is associated with a range of negative health outcomes, whereas, increased and regular or sustained physical activities improves the physical, mental, emotional, social and intellectual well-being of any individual $[14,15]$

Reproductive health problems of the girl-child which frequently hinders them from benefiting maximally in educational and few available physical/sporting activities, includes menstrual cramps, and syndrome, occasional excessive whitish discharge from the virgina, difficulty in controlling menstrual flow every 45 (forty-five) days interval, occasional pain experienced while urinating, occasional frequent passing of urine, itching in the area of the virgina, irregular menstruation, occasional laceration or (sore) around the virgina due to prolonged use of sanitary pads. All these could be regarded as a few of the numerous reproductive health problems that confront the girlchild, which invariably occasionally prevents them from benefiting maximally from both educational process and regular participation in physical/sporting activities of the Secondary Schools and Universities they attend [2].

Out of these few mentioned reproductive health problems of the girl-child, menstruation seems to top the list of such problems that hinder them from regular school attendance and active participation in few provided sporting activities of the Secondary Schools and Universities they attend. Hence the need to conduct this study that seeks to examine "Sports Participation and Education of the Girl-Child Perceived Implications of Reproductive Health Problems and Male Dominance: University Sports Administration Experience".
Statement of the problem: All round education of the Girl-Child, just like their male counterparts, must include unhindered access to wholesome participation in regular physical/sporting activities, which will invariably work together with classroom academic instructions, to produce the much required future mothers, that will give rise to healthier and socially well-adjusted citizens of their various nations.

However this ideal situation tends to be a mirage, especially in developing countries like Nigeria, where the girl-child (female undergraduates) are faced with inevitable but controllable reproductive health problems, coupled with paucity of adequately, trained sports personnel's, near lack of proper funding for sports facilities, to crown them up - perceived male dominance over the females virtually in every sporting activity, in any typical university campuses in Nigeria.

One may not need any statoscope to observe sadly, that it is always the male undergraduates that regularly besiege even the few sports facilities, university authorities intentionally construct near the female hostels meant for the girls. Thereby giving little or no opportunity for the female undergraduates to regularly exercise themselves at their convenient times.

It is on the premise of this worrisome scenario that motivated the researcher to undertake this study, which seeks to examine "Sports Participation and Education of the Girl-Child Perceived Implications of Reproductive Health Problems/ Male dominance: University Sports Administration Experience.

Research questions: The following formulated research questions will guide the study.

1. Do reproductive health problems determine female undergraduates participation in class, lectures and sporting activities in the universities?

2. Do the poorly maintained/funded sports facilities determine female undergraduates participation in sporting activities in the universities?

3. Do the perceived male Dominance over their female counterparts in virtually all sporting activities determine female undergraduates participation in sporting activities in the universities?

Hypothesis: The following formulated hypotheses will be tested at 0.05 level of significance:

1. Reproductive health problems do not significantly determine female undergraduates participation in class lectures and sporting activities in the universities.

2. Poorly funded and maintained existing spots facilities do not significantly determine female undergraduates participation in sporting activities of the universities

3. Perceived Male dominance over their female counterparts in virtually all sporting activities, do not significantly determine female undergraduates participation in sporting activities in the universities.

\section{Methodology}

Frequency count, percentages, standard Deviation (SD) and Chisquare $\left(\mathrm{X}^{2}\right)$ statistics were used to analyze the data collected. Frequency counts and percentages were used for the description of bio-data of the respondents. While Mean and Standard Deviation (SD) were used to answer the research questions, and a mean of 2.50 was set as the cutoff point for decision rule for each item on the instrument. Hence any 
Eugene AC (2019) Female undergraduate sports participation and adequate education, perceived implications of reproductive health problems/male dominance: University sports administration experience

item that had a mean of 2.50 or above was considered a determinant, while any item with a mean below 2.50 was considered as not a determinant. Then Chi-square statistics was used to test the research hypotheses at 0.05 alpha level of significance. Chi-square being a nonparametric statistic, which is more appropriately used for analyzing data obtained from different opinions, views and observations by a large population. Since the data for this study was collected from a large number of respondents, the chi-square statistics was considered as most appropriate for testing the research hypothesis.

\section{Results}

This section presents the descriptive analysis of biodata, mean analysis of responses, results of hypotheses that were tested, presented and discussed (Table 1).

Respondents Demographic Data were simply categorized under the following:-

1. Regular University Female athletes

2. Non-Regular University Female athletes

3. Respondents were all female university undergraduates at different levels of study and courses of pursuits. Demographic data of the respondents on sex revealed that all the 263 population were female undergraduates. Only the year on (fresh) students were left out, since majority of them are yet to settle down properly. The subjects used for the study therefore comprised female undergraduates from year 2 upwards, who were freely selected irrespective of one's faculty or department. Sports directors of Faculties were used as the research assistants for the administration and collection of the questionnaire from the various faculties.

Table 1 therefore showed that out of the 263 respondents (all females) $110(41.8 \%)$ were regular university athletes, while $165(58.2 \%)$ were non-regular university athletes.

\section{Discussion of findings}

This section will discuss the major findings of this research work which will be done in line with the results of the hypotheses as tested.

The Table 2 above revealed that the mean responses on reproductive health problems was 2.60 , which was above the cutoff point of 2.50 which therefore indicates that reproductive health problems (top on the list is painful menstruation) determine the participation of female undergraduates participation both in class lectures and sporting activities.

On poor funding of sports facilities by university authorities and poor maintenance of few existing sports facilities, determine significantly female undergraduate participation in sporting activities in the universities

Equally, on the research question of male dominance over the girls in virtually all sports, whereby even the few sports facilities intentionally constructed near the female hostels, were on daily basis invaded and monopolized by the male undergraduates, was 2.62 , which also was above the cut-off point of 2.50, signifying that the issue of males undergraduates dominance in all the sporting activities, significantly determine female undergraduates participation in university sporting activities.

$\mathrm{X}^{2}=84.18, \mathrm{df} 3, \mathrm{p}<0.05$
Table 1. Demographic data of the respondents on sex revealed that all the 263 population were female undergraduates

\begin{tabular}{|c|c|c|c|c|c|}
\hline Sex & & Freq & uency & & percentage \\
\hline $\begin{array}{l}\text { Female undergraduate students from } \\
\text { different departments and at various } \\
\text { levels of study and courses of study }\end{array}$ & 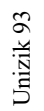 & $\begin{array}{l}n \\
\infty \\
2 \\
0\end{array}$ & 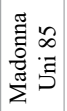 & 푤 & $100 \%$ \\
\hline $\begin{array}{l}\text { Regular female undergraduate } \\
\text { University athletes }\end{array}$ & & & 10 & & $41.8 \%$ \\
\hline $\begin{array}{l}\text { Non-Regular undergraduate University } \\
\text { athletes }\end{array}$ & & & 53 & & $58.2 \%$ \\
\hline Total & & & 63 & & $100 \%$ \\
\hline
\end{tabular}

Table 2. Mean analysis of responses of questionnaire

\begin{tabular}{|l|c|c|}
\hline Variables & Mean $(\overline{\mathrm{X}})$ & SD \\
\hline Reproductive health problems & 2.60 & 0.87 \\
\hline Poorly funded and non-maintenance of available sports activities & 2.57 & 0.87 \\
\hline Male Dominance over the females in virtually all sporting activities & 2.61 & 0.86 \\
\hline
\end{tabular}

Table 3 portrayed that the calculated chi-square value of 84.18 was greater than the chi-square critical value of 7.82 , with $\mathrm{df}=3$ @ 0.05 alpha level. Which means that the hypothesis which postulated that reproductive health problems do not significantly determine female undergraduates participation both in class lectures and sporting activities of the university is rejected.

$$
\mathrm{X}^{2}=121.29 \text {, df } 3, \mathrm{p}<0.05
$$

Table 4 showed that the calculated Chi value of 121.29 was indeed greater than the chi-square critical value of 7.82 , with $\mathrm{df}=3$ @ 0.05 alpha level. Which means invariably that the hypothesis which stated that poor funding of sports and poorly maintained sports facilities of the universities did not significantly determine female undergraduates participation in university sporting activities was rejected.

$$
\mathrm{X}^{2}=121.29 \text {, df } 3, \mathrm{p}<0.05
$$

Table 5 of this research work showed that the calculated Chi value of 121.29 was greater than the chi-square critical value of 7.82 , with $\mathrm{df}=3$ @ 0.05 alpha level. This means that the hypothesis which postulated that perceived male dominance in virtually all sporting activities do not determine female undergraduate participation in sporting activities in the universities in the universities did not significantly determine the female undergraduates participation in sporting activities in the university was rejected.

Which implies that implies that, male dominance in all sporting activates including their visible near invasion of virtually all sports facilities and available open spaces, even those the university authorities intentionally constructed or provided for use by the female undergraduates near the female hostels, very significantly determined female undergraduates participation in sporting activities in the universities.

Major findings: The major findings of this research work were discussed based on the result of the postulated hypothesis which were tested at 0.05 Alpha level.

With reference to the issue of reproductive health problems not significantly determining female undergraduates participation in sporting activities of the universities and attendance to lecturers; reproductive health problems determine the participation of female undergraduates of universities in sporting activities and class lectures. This is in line with Mengistu and Melku (2013) who in their exploratory qualitative study of sexual and reproductive health problems and 
Eugene AC (2019) Female undergraduate sports participation and adequate education, perceived implications of reproductive health problems/male dominance: University sports administration experience

Table 3. Summary of Chi-Square Analysis on Reproductive health problems as it determined the participation of female undergraduates in both class lectures and sports activities

\begin{tabular}{|c|c|c|c|c|c|c|c|}
\hline Response & Fo & Fe & $\mathbf{X}^{2}$ Cal & $\mathbf{X}^{2}$ Cri & Df & a & Remark \\
\hline SA & 65 & 65.75 & - & - & - & - & - \\
\hline A & 125 & 65.75 & - & - & - & - & - \\
\hline D & 49 & 65.75 & 84.18 & 7.82 & 3 & 0.05 & Significant \\
\hline SD & 24 & 65.75 & - & - & - & - & - \\
\hline Total & 263 & 263.00 & - & - & - & - & - \\
\hline
\end{tabular}

Table 4. Summary of $\left(\mathrm{X}^{2}\right)$ Chi-square analysis on poorly, funded and maintained existing sports facilities as it determines the female undergraduates participation in sporting activates of the universities

\begin{tabular}{|c|c|c|c|c|c|c|c|}
\hline Response & Fo & Fe & $\mathbf{X}^{2}$ Cal & $\mathbf{X}^{2}$ Cri & Df & a & Remark \\
\hline SA & 63 & 65.75 & - & - & - & - & - \\
\hline A & 137 & 65.75 & - & - & - & - & - \\
\hline D & 48 & 65.75 & 121.29 & 7.82 & 3 & 0.05 & Significant \\
\hline SD & 15 & 65.75 & - & - & - & - & - \\
\hline Total & 263 & 263.00 & - & - & - & - & - \\
\hline
\end{tabular}

Table 5. Summary of Chi-square analysis on perceived male dominance in virtually all sporting activities do not determine female undergraduate participation in sporting activities in the universities

\begin{tabular}{|c|c|c|c|c|c|c|c|}
\hline Response & Fo & Fe & $\mathbf{X}^{2}$ Cal & $\mathbf{X}^{2}$ Cri & Df & a & Remark \\
\hline SA & 63 & 65.75 & - & - & - & - & - \\
\hline A & 137 & 65.75 & - & - & - & - & - \\
\hline D & 48 & 65.75 & 121.29 & 7.82 & 3 & 0.05 & Significant \\
\hline SD & 15 & 65.75 & - & - & - & - & - \\
\hline Total & 263 & 263.00 & - & - & - & - & - \\
\hline
\end{tabular}

services needs of university female students in south-East Ethiopia, revealed in their findings that university female students face many reproductive health problems that affect both their academic work and sports participation, hence they needed better reproductive health services in their university clinics to make it youth friendly.

In respect to poorly funded and poor maintenance of sports facilities as a determinant of female undergraduates participation in sports; result of the finding showed that poor funding and poorly maintained sports facilities in universities determine significantly female undergraduates participation in university sporting activities. This is in line with Ahmed (2016) who stated that the poor state of most Nigerian universities sport facilities and funding contributes immensely to declining level of female undergraduates participation in sporting activities in universities in Nigeria.

Furthermore, result of this study here also supports Ekanem (2015) who stated that the existence of sports facilities is of vital importance in the conduct of sports and games competitions and participation.

With reference to the issue of male undergraduates dominance over their female counterparts in virtually all the sporting activities, result of the findings show that it significantly determined female undergraduates participation in sporting activities in universities, which is in line with Babatunde (2001) whose study revealed that gender is a strong determinant of sports participation among undergraduates in first generation Nigeria universities. Furthermore, they averred that male undergraduate students participate in sports more than their female counterparts.

\section{Conclusion}

Based on the findings of this study, the following conclusions were arrived at:
1. Reproductive health problems of the undergraduate female students of universities significantly determine their low participation in university sporting activities and class lectures attendance.

2. Poor funding and poor maintenance of sports facilities in universities was concluded as significant determinant of female undergraduates low participation in sporting activities in universities.

3. From the result of the findings of this study, it was also concluded that male undergraduate dominance over their female undergraduate counterparts in virtually all sporting activities, and the male undergraduates invasion of even the few sports facilities provided by the universities authorities, for use by the female undergraduates; determine significantly, female undergraduates low participation in sporting activities in universities in Nigeria.

\section{Recommendations}

Based on the conclusions of this study, the following recommendations are hereby being proffered:

1. University clinics in Nigerian universities should be made to be youth (female) friendly, to encourage the female undergraduate students utilization of their services in solving their reproductive health problem, which most times prevent them from regular participation in sporting activities of the universities. Highly qualified nursing sisters should be deployed to all female hostels on permanent basis to serve as, hostel matrons to daily attend to the female undergraduate reproductive health problems.

2. Adequate attention need to be paid towards funding and maintenance of sports facilities in universities in Nigeria. Attractive and well maintained, indoors type of sports facilities constructed inside the female hostel complex will improve female undergraduates participation in universities sports activities.

3. In order to further minimize or reduce male undergraduates dominance over their female counterparts in sports participation in universities, strict restrictions should be put in place, debarring male undergraduates "invasion" of the few, sports facilities provided by the universities authorities near female hostels, for use by the female undergraduates. Such restrictions will definitely encourage and enlist higher female undergraduates participation in universities sports activities, at their own convenience.

\section{References}

1. Ahmed AA (2016) Perceived factors influencing recreational participation of female students of Adekunle Ajasin University, Akungba Akoka, Ondo state, Nigeria. Journal of University of Port Harcourt. Nigeria Association for Physical health, education, Recreation, Sports and Dance.

2. Akude AE (2018) Adolescent girls reproductive health problems and role of the schoo in addressing the issues in Anambra state Nigeria. Unpublished M.Sc Thesis Nnamdi Azikiwe University, Awka.

3. Alagbu CE (1999) Factors affecting perception and attitude of parents towards their female off-springs participation in competitive sports in selected federal government Girls Colleges in Nigeria. Unpublished Ph.D Thesis University of Ibadan.

4. Alagbu CE (2010) Mass participation in sports in universities by undergraduates students: A road map to building a total man. African journal of Studies in Education.

5. Babatunde SO (2001) Socio-cultural determinants of sports participation among undergraduates in First generation Nigerian Universities. Unpublished PhD Dissertation University of Lagos. 
Eugene AC (2019) Female undergraduate sports participation and adequate education, perceived implications of reproductive health problems/male dominance: University sports administration experience

6. Banks P, Jahoda A, Dannan D, kemp J, Williams V, et al. (2010) Supported employment for people with intellectual disability: The effects of job breakdown on psychological well-being. Journal of Applied Research in Intellectual Disabilities 23: 344-354.

7. Ekanem E (2015) Strategies for improving school sports programmes in the Universal Basic Education; Journal of Nigerian Association of Physical and health Education, Recreation, Sports and Dance 2: 128-134.

8. Eze CN (2014) Racializing disability, Disabling race: Policing race and mental status. Berkley Journal of Criminal Law.

9. Goreczny AJ (2016) Do inclusive work environments matter? Effects of communityintegrated employment in quality of life for intellectual disabilities. Research in Developmental Disabilities 4: 53358-53366.

10. WHO (2011) Children with disabilities in the context of disaster: A social vulnerability perspective (PDF) Child development.
11. Udegbe OC (2018) Effects of pilates training on body mass index (BMI) of obesed secondary school students in Awka South Local Government Area, Anambra State Nigeria.

12. WHO (2009) Global recommendation on physical activity for health. Retrieved 13/7/2018. Available at http://www.who.int/neds/prevention/physical-activity/en/

13. Palensic Z (2014) Measurement issues and poor adjustments for physical activity and sleep undermine sedentary behavior research. Journal Kinesiology 46: 135-146. Retrieved from http://hrcak.srce.hr/123743

14. Palencia IA (2018) The effects of transport mode use on self-percieved health, mental health, and social contact measures: A cross-sectional study. Environmen/international 120: 199-206.

15. Mengistu TS and melku AT (2013) Sexual and reproductive health problems and service needs of university female students in South East Ethiopia: Exploratory qualitative study. Science Journal of Public health 1: 184-188.

Copyright: (C2019 Eugene AC. This is an open-access article distributed under the terms of the Creative Commons Attribution License, which permits unrestricted use, distribution, and reproduction in any medium, provided the original author and source are credited. 